DOI 10.18551/rjoas.2021-10.28

\title{
EFFECT OF VARYING CONCENTRATIONS OF SPENT LUBRICATING OIL CONTAMINATED SOILS ON GERMINATION AND SEEDLING GROWTH OF ADANSONIA DIGITATA (LINN)
}

\author{
Ojo M.O. \\ Elizabeth Ehi-Ebiewele Biodiversity Linkage Center, Forestry Research Institute of Nigeria, \\ Ibadan, Nigeria
}

Asinwa I.O.

The Rainforest Research Station (RFRS), Forestry Research Institute of Nigeria, Ore, Ondo State, Nigeria

Ayeni O.D.

Department of Environmental Modelling and Biometrics, Forestry Research Institute of Nigeria, Ibadan, Nigeria

Geply O.A., Oyedeji O.F.

Forestry Research Institute of Nigeria, Ibadan, Nigeria

Adelakun K.M.

Federal College of Wildlife Management of Forestry Research Institute of Nigeria, New Bussa, Niger State, Nigeria

*E-mail: adebayo.olaoluwa@pg.funaab.edu.ng

\begin{abstract}
The effect of Spent Lubricating Oil (SLO) contaminated soils on seeds and seedlings of Adansonia digitata (Linn) were investigated to assess the level of SLO that will produce the best seedling performance. The experimental design used was Completely Randomized Design (CRD) with four replicates. The spent lubricating oil levels were $0 \mathrm{ml}$ (Control), $20 \mathrm{ml}$, $40 \mathrm{ml}, 60 \mathrm{ml}, 80 \mathrm{ml}, 100 \mathrm{ml} 120 \mathrm{ml}, 140 \mathrm{ml}$ with $3 \mathrm{~kg}$ of top soil. Parameters assessed were germination percentage $(\%)$, seedlings height $(\mathrm{cm})$, stem diameter $(\mathrm{mm})$, leaf production and leaf area $\left(\mathrm{cm}^{2}\right)$. The result showed that seedlings in oil contaminated soil gave different responses to the level of spent lubricating oil concentrations, T1 (Control) gave the best performance in all parameters assessed; seedling height $(12.77 \mathrm{~cm})$, leaf production $(7.6)$, stem diameter $(0.85 \mathrm{~mm})$, and leaf area $\left(38.60 \mathrm{~cm}^{2}\right)$. There was no significant difference among treatments in seedling height $(\mathrm{cm})$, leaf area $\left(\mathrm{cm}^{2}\right)$ and leaf production at $5 \%$ level of probability but there were significant difference among treatments in stem diameter $\left(\mathrm{cm}^{2}\right)$ at $5 \%$ level of probability. It was therefore recommended that Adansonia digitata should be adopted for reclamation of land where the use of Spent Lubricating Oil is prominent to an extent.
\end{abstract}

\section{KEY WORDS}

Adansonia digitata, spent lubricating oil, germination, growth.

Adansonia digitata (Linn) is most wide spread of tree species on the African continent found in hot dry savannah to sub Saharan Africa; the common name is African baobab tree. The trees usually grow as solitary individuals and are large distinctive. Each leaf comprises of five leaflets. The African baobab fruit can grow up to $25 \mathrm{~cm}$ long and it can contain $50 \%$ more calcium than spinach (Claire, 2008). Adansonia digitata is a fast growing plant. It takes the seed seven to twelve days to germinate and start growing under favorable soil condition. It can thrive in difficult terrain, harsh weather, stony area, nutrient depleted area etc., because it contains hard - fibre (FAO, 1988). Due to its ability to thrive in these conditions, 
Adansonia digitata will be adopted in this study to determine its growth response to different levels of spent lubricating oil contaminated soils, which can serve in reclaiming oilcontaminated area, eradicating encroachment and controlling environmental pollution. Furthermore the spent lubricating oil (waste engine oil) is usually obtained after servicing and subsequently draining used oil from automobiles and generator engines. The disposal of spent lubricating oil into drainage systems on open vacant plots and farmlands in Nigeria is a common occurrence and is mostly done by auto mechanics and allied artisans with workshop on the road side and open places (Agbogidi, 2010). According to Wang et al. (2010), some of the spent lubricating oil may have foreign substances including synthetic polychlorinated biphenyls and higher concentrations of poly aromatic hydrocarbon (PAHS) and heavy metal which constitutes environmental risk to man, other animals and plants. Spent lubricating oil according to Atuanya, (1987) affects soil physical, biological and chemical properties. However, used oil is a very serious waste management problem and is dangerous to the environment (Agbogidi, 2010). Also the presence of toxic oil constituents and heavy metals may not be ruled out as their influence on crop plant is quite enormous (Agbogidi et al., 2007).

The spent lubricating oil contaminated soil has been used to raise tomato, red beans, pepper etc, in the past to determine their growth response in such soils (Annoliefo and Vwioka, 2000), but little or no research work has been carried out on the adaptation of Adansonia digitate in the area where such contaminant is prominent as a means for reclamation. Therefore .this study was carried out to examine the germination and growthresponse of Adansonia digitata seeds and seedlings to different levels of spent lubricating oil contaminated soils.

\section{MATERIALS AND METHODS OF RESEARCH}

The experiment was carried out at the Nursery of Forestry Technology Department of Federal College of Forestry, Ibadan, Oyo state Nigeria. The nursery is located at Jericho area of Ibadan Northwest Local Government Area of Oyo state which falls on latitude $7^{0} 26^{\prime} \mathrm{E}$ and longitude $3^{0} 5 l^{\prime} \mathrm{N}$ of the Greenwich meridian. Its annual rainfall is about $1300-1500 \mathrm{~mm}$ while the mean annual temperature is $26^{\circ} \mathrm{C}$, the average relative humidity is about $65 \%$ (FRIN meteorological station, 2018).

The seeds of $A$. digitata were collected from a mother tree within the Federal College of Forestry, Ibadan. Top soil was collected at Agricultural Technology Department AGT farm practical plot within the College premises. Spent lubrication oil was collected from the mechanic section of the College. The weighing balance used for the experiment was obtained from the Agricultural Technology Department; polythene pots, pen, notebook, meter rule, paper cello tape were procured at Aleshinloye market, Ibadan, Oyo State.

\section{METHODS OF RESEARCH}

The seeds of Adansonia digitata were extracted by crushing the fruits carefully to prevent damage and viability loss to the seed. Impurities were removed from the extracted seeds by hand sorting and washed in running water. During this process, seeds that were not viable were seen floating they were removed and discarded while the viable seeds were subjected to pretreatment by soaking in boiled water and then left for 24 hours before sowing (Oboho and Ahanon, 2017). One hundred and sixty seeds were used for the experiment. A set of 4 replicates of 5 seeds were sown in polythene pots of size $24.5 \mathrm{~cm} \times 140 \mathrm{~cm}$ filled with the mixture of $3 \mathrm{~kg}$ of topsoil and spent lubrication oil at varying levels while seeds sown in $3 \mathrm{~kg}$ of topsoil only served as the control. The treatment combinations are presented below:

- Treatment $1 \rightarrow 3 \mathrm{~kg}$ of top soil (control);

- Treatment $2 \longrightarrow 3 \mathrm{~kg}$ of top soil $+20 \mathrm{ml}$ of S.L.O;

- Treatment $3 \longrightarrow 3 \mathrm{~kg}$ of top soil $+40 \mathrm{ml}$ of S.L.O;

- Treatment $4 \longrightarrow 3 \mathrm{~kg}$ of top soil $+60 \mathrm{ml}$ of S.L.O; 
- Treatment $5 \rightarrow 3 \mathrm{~kg}$ of top soil $+80 \mathrm{ml}$ of S.L.O;

- Treatment $6 \longrightarrow 3 \mathrm{~kg}$ of top soil $+100 \mathrm{ml}$ of S.L.O;

- Treatment $7 \rightarrow 3 \mathrm{~kg}$ of top soil $+120 \mathrm{ml}$ of S.L.O;

- Treatment $8 \rightarrow 3 \mathrm{~kg}$ of top soil $+140 \mathrm{ml}$ of S.L.O.

Germination was taken to have occurred when the plumule emerge above the potting mixture in the polythene pots. Germination assessment was carried out daily and recorded. Germination percentage of seeds from each treatment was determined following the procedure highlighted by Abdul-Haleem and Shaieny, (2015), where seeds that germinated from each treatment were added cumulatively and the germination percentage in each treatment was calculated as:

$$
\text { Percentage germination }=\frac{\text { No of germinated seeds }}{\text { No of seeds sown }} \times 100
$$
seeds.

Therefore simple percentage was used to determine the effect of SLO on A. digitata

The experiment was set up in a Completely Randomized Design (CRD). There were eight treatments; each treatment was replicated four times with five seeds per pot making a total of 160 seeds. Growth parameters assessed include; Seedling Height $(\mathrm{cm})$ which was measured using graduated metric ruler, Stem Diameter $(\mathrm{mm})$ measured with Vernier caliper, Number of leaves was done visually while Leaf Area $\left(\mathrm{cm}^{2}\right)$ was determined using formula adopted by Clifton-Brown and Jones (1997). Data collected were subjected to descriptive statistics and Analysis of Variance (ANOVA), where significant, means were separated using Duncan Multiple Range Test (DMRT).

\section{RESULTS AND DISCUSSION}

Table 1 show that germination commenced after 11days of sowing and it was erratic extending over a long period. Seed pretreatment using hot water enhanced seed germination of $A$. digitata as observed in the control experiment $(75.00 \%)$. This result is in line with the findings of Oboho and Ahanon, (2017). Germination was affected by the presence of spent lubricating oil (SLO). Significant reduction was observed in the germination percentage of $A$. digitata seeds sown in oil contaminated soils ranging from $55.00 \%$ ( $3 \mathrm{~kg}$ of topsoil $+20 \mathrm{ml}$ of SLO) and $10.00 \%$ (3kg of topsoil $+140 \mathrm{ml}$ of SLO) when compared with seeds sown in uncontaminated soils $(75.00 \%)$, days of germination were also delayed as it took seeds in the contaminated soil longer time to germinate according to the level of concentration of SLO that was applied.

\begin{tabular}{|c|c|c|c|c|}
\hline \multicolumn{5}{|c|}{ Treatment No of seeds sown No of seeds germinated Days of emergence Germination \% } \\
\hline $\mathrm{T}_{1}$ & 20 & 15 & 11 & 75.00 \\
\hline $\mathrm{T}_{2}$ & 20 & 11 & 18 & 55.00 \\
\hline $\mathrm{T}_{3}$ & 20 & 9 & 20 & 45.00 \\
\hline $\mathrm{T}_{4}$ & 20 & 7 & 31 & 35.00 \\
\hline $\mathrm{T}_{5}$ & 20 & 7 & 31 & 35.00 \\
\hline $\mathrm{T}_{6}$ & 20 & 4 & 33 & 20.00 \\
\hline $\mathrm{T}_{7}$ & 20 & 3 & 43 & 15.00 \\
\hline $\mathrm{T}_{8}$ & 20 & 2 & 48 & 10.00 \\
\hline
\end{tabular}

Table 1 - Germination Percentage of Adansonia Digitata Seedlings

The failure of some of the seeds to germinate may be ascribed to increase in soil temperature due to the nature of the contaminated soil (Olayinka and Arinde, 2012). All the seeds sown in various levels of contaminated soil germinated but the number significantly reduced with increasing oil level in the soil, $3 \mathrm{~kg}$ of topsoil $+140 \mathrm{ml}$ of SLO (T8) managed and struggled to germinate but the seedlings showed evidence of unhealthiness, yellowing of 
leaves, necrosis and growth retardation, this supported the findings of De Jong, (1980) and Ogbo (2009) that embryo of seed tend to be injured or killed if it comes in contact with spent oil and also contamination with spent oil also cause growth retardation in plants.

Figure 1 show that $T_{1}$ (control) had the highest performance in height with a mean value of $12.77 \mathrm{~cm}$ followed by $\mathrm{T}_{2}(20 \mathrm{ml}$ of $\mathrm{SLO}+$ top soil) with a mean value of $9.63 \mathrm{~cm}$, while the least performance was observed in T6 $(140 \mathrm{ml}$ of SLO+ top soil) with a mean value of 3.1 $\mathrm{Icm}$. Furthermore, the various reduction in growth characteristics measured were spent lubricating oil concentration dependent, this was brought about by the effect of the SLO in the soil which inhibited the growth of the plants; although $\mathrm{T}_{2}(20 \mathrm{ml}$ of SLO + top soil) performed best when compared to other seedlings in contaminated soils. This result supported the findings of Agbogidi (2010) who reported that since uptake of water and salt is carried out by root undisturbed, seedlings could have absorbed enough nutrients compared to the seedlings exposed to soil treatment with diverse levels of spent lubricating oil. Also Esenwo et al, (2006) had earlier reported similar observation that spent engine oil affect plant growth as it interferes with soil aeration, mineral availability, plant water relation and suitable warmth that are necessary for plant growth and development. However, table 2 showed that there was no significant difference among the treatments at $5 \%$ level of probability.

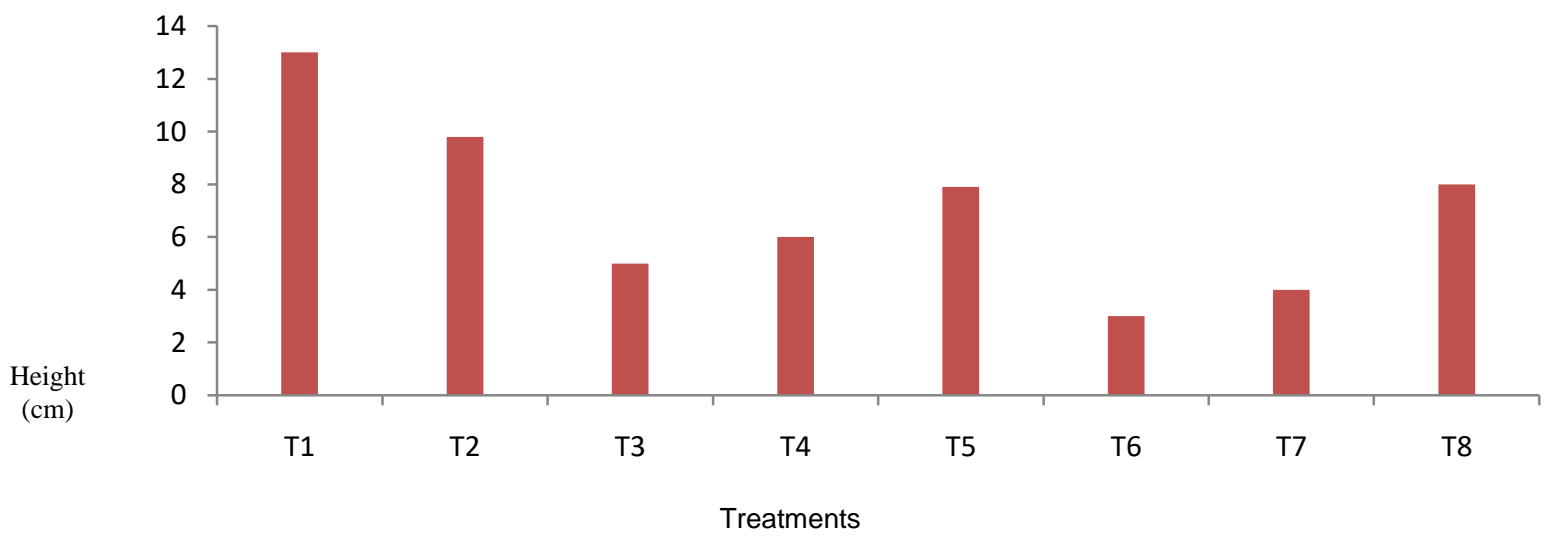

Figure 1 - Mean Height (cm) of $A$. digitata Seedlings

Table 2 - Analysis of Variance for Seedling Height

\begin{tabular}{llllll}
\hline SV & DF & SS & MS & F & P-VALUE \\
\hline TRT & 7 & 318.62 & 45.51 & $1.15 \mathrm{NS}$ & 0.37 \\
ERROR & 24 & 949.14 & 39.54 & & \\
TOTAL & 31 & 1267.77 & & & \\
\hline
\end{tabular}

Note: Ns - not significance $(p>=0.5)$.

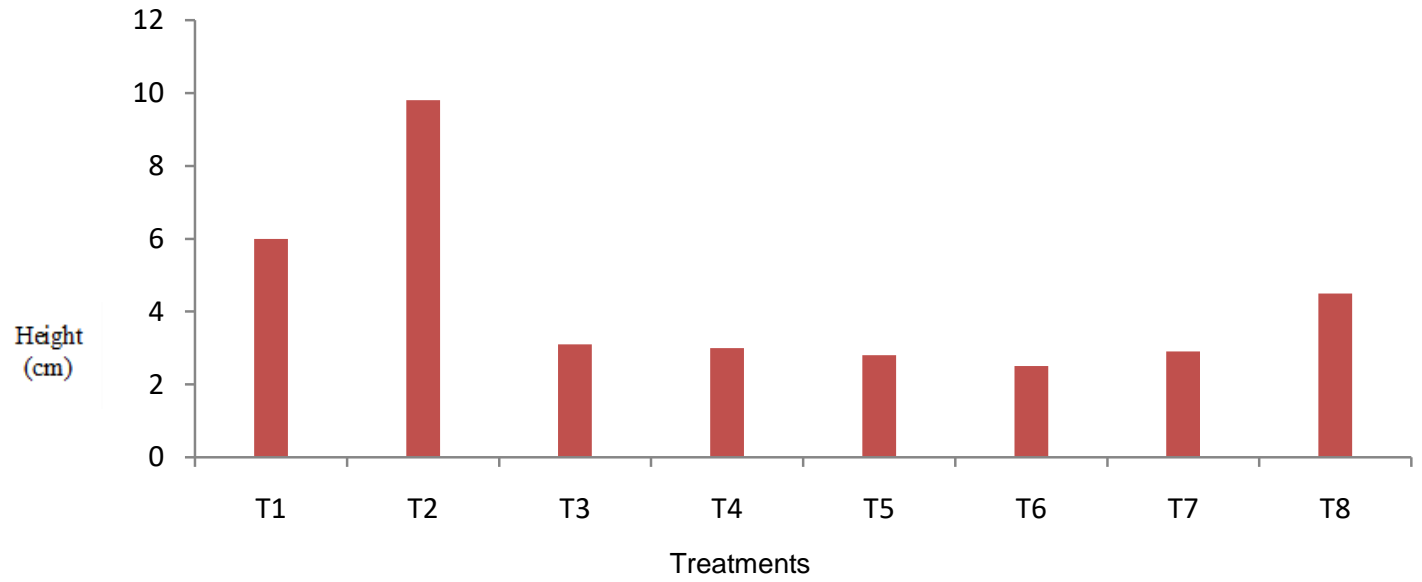

Figure 2 - Mean Leaf production for $A$. digitata Seedlings 
Figure 2 presents the mean leaf production of $A$. digitata seedlings raised in $\mathrm{T}_{1}$ (control) gave the highest mean leaf production of 7.6 followed by $\mathrm{T}_{2}(20 \mathrm{ml}$ of SLO + top soil) with a mean value of 6.2 , while $\mathrm{T}_{8}(140 \mathrm{ml}$ of SLO + topsoil) had the least performance with mean value of 2.43. The result showed that SLO affected the leaf production in plants negatively but at lower concentrations the seedlings can still adapt. Consequently, seedlings in higher concentrations exhibited yellowing of leaves, shrinkness as well as stunted growth. This findings is in consonance with Atuanya (1987) who pointed out that as hydro carbon from oil contaminated soils accumulate, translocation is affected due to obstruction of the xylem and phloem vessels, hence reduction in photosynthesis which tends to reduce the dry matter components of the plants. Also Ogbo, (2009) reported highest mean leaf production of Arachis hypogaea for each control treatment while soils polluted with SLO had lower numbers of leaves because the contaminants were phytotoxic to seedling growth. However there was no significant difference among the treatments at $5 \%$ probability level.

Table 3 - Analysis of Variance for Seedling Height

\begin{tabular}{llllll}
\hline SV & DF & SS & MS & F & P-VALUE \\
\hline TRT & 7 & 32.62 & 4.63 & $0.63 n s$ & $>0.05$ \\
ERROR & 24 & 226.14 & 9.42 & & \\
TOTAL & 31 & 258. & & & \\
\hline
\end{tabular}

Note: $n s-$ not significant ( $p>=0.05)$.

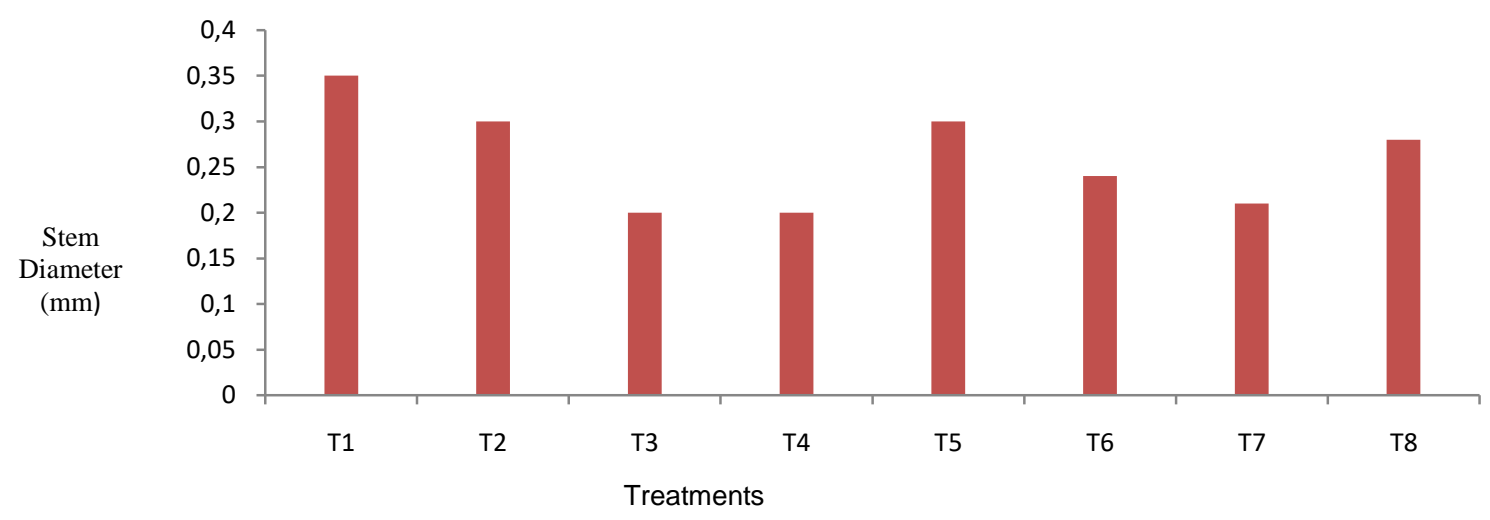

Figure 3 - Mean Stem Diameter $(\mathrm{mm})$ for $A$. digitata Seedlings

There were significant differences in the effect of spent lubricating oil on stem diameter of $A$. digitata seedlings $(\mathrm{P} \leq 0.05)$.

$\mathrm{T}_{1}$ (control) had the highest performance in stem diameter with mean value of $0.85 \mathrm{~mm}$, followed by $T_{2}$ with mean value of $0.52 \mathrm{~mm}$, while $T_{7}$ and $T_{8}$ had the least mean value of $0.21 \mathrm{~mm}$. The seedling reacted to different levels of the contaminants, though the performance reduced with increased concentrations of the SLO. The spent lubricating oil was inhibitory to the growth of the seedlings, this could be attributed to large amount of hydrocarbons in used oil (Wang et al., 2000). This report was in consonance with the findings of Agbogidi and Ejemete (2005) who noted that the level of oil in soil seemed to exert significant influence on plant species and agricultural lands due to the presence of heavy metals which is responsible for the reduction in plant growth characters mobilization as well as the metabolic activities of the plants. Table 4 indicated that there were significant differences among the treatments used at $5 \%$ level of probability.

Table 4 - Analysis of variance for Stem Height

\begin{tabular}{llllll}
\hline SV & DF & SS & MS & F & P-VALUE \\
\hline TRT & 7 & 0.06 & 0.01 & $0.18^{*}$ & 0.03 \\
ERROR & 24 & 1.18 & 0.05 & & \\
TOTAL & 31 & 1.24 & & & \\
\hline
\end{tabular}

Note: Significant at $5 \%$ level of profitability $(p>=0.05)$. 


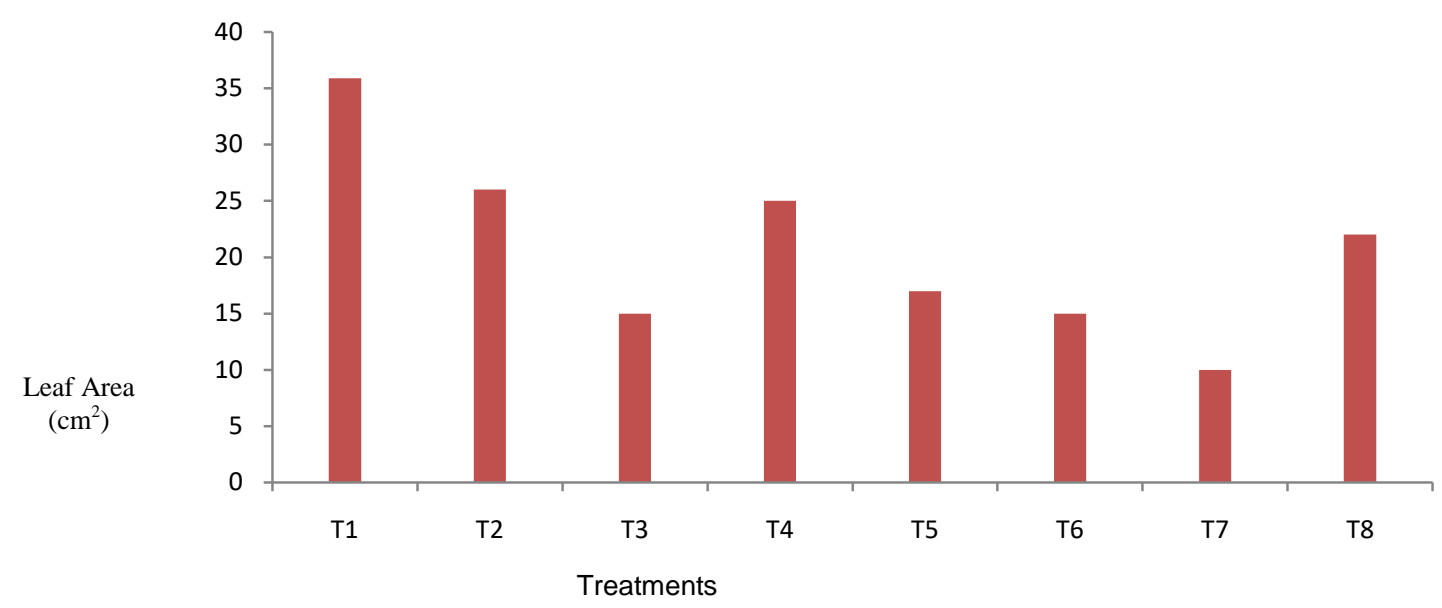

Figure 4 - Mean Leaf Area $\left(\mathrm{cm}^{2}\right)$ for A. digitata Seedlings

Figure 4 above showed that T1 (control) had the highest mean leaf area of $\left(38.60 \mathrm{~cm}^{2}\right)$, followed by $\mathrm{T}_{2}\left(20 \mathrm{ml}\right.$ of SLO + top soil) $\left(26.68 \mathrm{~cm}^{2}\right)$, the least value was observed in T8 $\left(140 \mathrm{ml}\right.$ of SLO+ topsoil) with a mean value of $10.65 \mathrm{~cm}^{2}$. The reduction in leaf area could be ascribed to the effect of SLO which has led to distortion and reduction of stomata per unit area of the leaf thus affecting photosynthetic process and consequently, the amount of photosynthetic produced. This result is in support of the findings of Agbogidi et al. (2007) who noted that the presence of toxic oil constituents and heavy metals may not be ruled out as their influences on plants are quite enormous.

Table 5 indicated that there was no significant difference among the treatments at $5 \%$ level of probability.

Table 4 - Analysis of variance for Leaf Area

\begin{tabular}{llllll}
\hline SV & DF & SS & MS & F & P-VALUE \\
\hline TRT & 7 & 2320.94 & 331.56 & $1.17 n s$ & 0.36 \\
ERROR & 24 & 6804.06 & 283.50 & & \\
TOTAL & 31 & 9125.00 & & & \\
\hline
\end{tabular}

Note: $n s$ - not significant ( $p>=0.5)$.

Table 5 - Mean values of effect of spent lubricating oil on stem diameter

\begin{tabular}{ll}
\hline Effect & Mean Stem Diameter \\
\hline Treatment & \\
Control & $0.85 \mathrm{a}$ \\
$20 \mathrm{ml} \mathrm{SLO}+3 \mathrm{~kg}$ top soil & $0.52 \mathrm{~b}$ \\
$40 \mathrm{ml}$ SLO $+3 \mathrm{~kg}+$ top soil & $0.41 \mathrm{c}$ \\
$60 \mathrm{ml}$ SLO $+3 \mathrm{~kg}+$ top soil & $0.35 \mathrm{~cd}$ \\
$80 \mathrm{ml}$ SLO $+3 \mathrm{~kg}+$ top soil & $0.32 \mathrm{~d}$ \\
$100 \mathrm{ml}$ SLO $+3 \mathrm{~kg}+$ top soil & $0.27 \mathrm{e}$ \\
$120 \mathrm{ml}$ SLO $+3 \mathrm{~kg}+$ top soil & $0.21 \mathrm{f}$ \\
$140 \mathrm{ml} \mathrm{SLO}+3 \mathrm{~kg}+$ top soil & $0.21 \mathrm{f}$ \\
LSD & 0.04 \\
\hline
\end{tabular}

Note: Means with the same letter are not significantly different from each other.

\section{CONCLUSION}

It is commonly known that spent lubricating oil is a soil contaminant, but no one has been able to quantify it and assign a number to the value of damage. SLO contaminates the soil and hereby does not give way for soil aeration. All treatments applied at different rates consequently affected the growth of Adansonia digitata at different levels. Also the study revealed that although seedlings of Adansonia digitata can thrive in spent lubricating oil contaminated soil, there is a level that it can tolerate. this can be seen in seedlings planted in 
$40 \mathrm{mls}, 60 \mathrm{mls}, 80 \mathrm{mls}, 120 \mathrm{mls}$ and $140 \mathrm{mls}$ of SLO contaminated soil as seedlings showed evidence of shrinkness, unhealthiness, yellowing of leaves, necrosis and growth retardation. It is therefore recommended that Adansonia digitata should be adopted for reclamation of land where the use of SLO is prominent to an extent.

\section{REFERENCES}

1. Abdel-Hakeem, A. H; WI-Shaieny, H. (2015). Seed germination percentage and early seedling establishment of five (Vigna unguiculata L. (walp), genotypes under salt stress. European Journal of Experimental Biology 5 (2): 22-32.

2. Agbogidi O. M, Ejemete O.R (2005). An assessment of the effects of crude oil pollution on soil properties, germination and growth of Gambaya albida (L). Uniswa. Res. J. Agric., Sci. Technol., 8(2): 148-155.

3. Agbogidi O.M (2010). Response of African oil bean (Pentaclethra macrophylla) (Benth) seeds to soil contaminated with spent lubricating oil. African Journal of Environmental Science and Technology, Volume4 (5): $492-494$.

4. Agbogidi O.M, Eruotor P.G, Akpairobi S.O, NnajiG.U (2007). Heavy metals content of maize Zeaniays) grown in soil contaminated with crude oil. International Journal of Botany, Volume 3(4): 384-3 89.

5. Annoliefo G.O, Vwioko D. E. (2000). Effect of spent engine oil as a soil contaminant on the growth of red beans and pepper. Journal of Agriculture Forestry and Fisheries, 1 .pp $21-25$.

6. Atuanya E.I (1987). Effect of waste engine oil pollution on physical and chemical properties of soil. A case study of waste oil contaminated delta soil in Bendel state. Nigerian Journal of Applied Science. Volume 5: 155-176.

7. Claire Soares, (2008). The tree life (and its super fruit), the independent Thursday, $17^{\text {th }}$, July, 2008.

8. Clifton-Brown, J. C, and Jones, M. B. (1997). The thermal response of leaf extension rate in genotypes of the grass Miscanthus: An important factor in determining the potential productivity of different genotypes. Journal of Experimental Botany. 48 15 73-158.

9. De Jong, E (1980). The effect of crude oil spill in cereals. Journal of environmental pollution, volume22: 187-196.

10. Ezenwo, G. J., Sam, S. M., Etuk, A. I. (2006). Effects of crude oil on germination and early seedling growth of Telfaria occidentalis. In Botany and Environmental Health, Akpan, G. and C, S. J. Odoemena (Eds). University of Uyo, Uyo, Nigeria, pp 93-96.

11. FAO (1988).Journal of terrains interim assessment. North America. 8(2), pp 216-222.

12. Oboho, E. G., Ahanon, E. C. (2017). Effects of different pretreatments on seed germination and watering regime on growth of Adansonia digitata (Linn) seedlings. Asian Journal of Science and Technology, Vol. 8; Issue 4, 4569-4573.

13. Ogbo, E. M. (2009). Effects of diesel fuel contamination on seed germination of four crop plants Arachis hypogaea, Vigna unguiculata, Sorghum bicolor and Zea mays. African Journal of Biotechnology 8; 250-253.

14. Olayinka, B. U. and Arinde O. O. (2012). Effects of Spent engine oil on germination and seedling growth of groundnut (Arachis hypogaea. L). Insight Ethnopharmacology 2; 5-9.

15. Wang J, Jia C.R, Wong C K, Wong P.K. (2000). Characteristics of polycyclicaromatic hydrocarbon created in lubricating aromatic hydrocarbon 5 created in lubricating oil. Water.air and soil pollution, 120: 38I-396. 